\title{
Artifacts and Archaeology from the Conquistador Hernando De Soto's Potano Encampment and the Lost Franciscan Mission
}

\author{
Fred A. White ${ }^{1,2}$ \\ ${ }^{1}$ The Archaeological Collections, Florida Archaeological Survey, Gainesville, FL, USA \\ ${ }^{2}$ Advisory Council and Collections, Appleton Museum of Art, College of Central Florida, Ocala, FL, USA
}

Email address:

nationalarchaeology@mail.com

\section{To cite this article:}

Fred A. White. Artifacts and Archaeology from the Conquistador Hernando De Soto's Potano Encampment and the Lost Franciscan Mission. International Journal of Archaeology. Vol. 4, No. 4, 2016, pp. 44-53. doi: 10.11648/j.ija.20160404.12

Received: June 1, 2016; Accepted: June 23, 2016; Published: July 6, 2016

\begin{abstract}
The historical site identified by the Florida Department of State, Bureau of Archaeological Research as Smithsonian Trinomial 8AAMR03538 was the location of one of Hernando de Soto's early camps during the 1539 entrada and was in later use during the sixteen and seventeenth century Spanish mission and ranching periods. This previously unknown First Spanish Cultural Period site named the White Ranch / De Soto site is located between Ocala and Gainesville, Florida on the wetlands associated with Orange Lake. Archaeological and documentary evidence confirms that this First Spanish mission period structure was a mission visita (mission without a resident priest) known as Apula and was understood to have been established in the late sixteenth century in the town of Potano known to have been visited by Hernando de Soto in 1539 . The artifact assemblage from the mission period structure brings the conclusion that 8AAMR03538 was also a location of religious activities associated with the Franciscan mission of San Buenaventura de Potano, that was relocated a short distance along the lake shore. This investigation contains a systemic analysis of the artifacts from the White Ranch / De Soto site 8AAMR03538 recovered between 2005 and 2013. The goal of this study and results are to obtain information about the Aboriginal inhabitants and the following European occupations. Detailed field notes, ground truth studies performed with penetrating radar, magnetic detection and geographic information systems were used to record and analyze the excavation site and its geospatial relationships. This new information offers significant evidence and documentation confirming that the site is where Hernando de Soto came to the area of Potano on August $12^{\text {th }} 1539$. His army began camping just to the south of this location from August $11^{\text {th }}$ to August $22^{\text {nd }}$ and then marched north through Potano to join him on the entrada at Aguacaleyquen. The ceramic and coin assemblages from the site strongly prove the visitation by De Soto and the later location for a Franciscan visita and ranch.
\end{abstract}

Keywords: Hernando De Soto, Potano, Franciscan Missions, Spanish, Florida

\section{Introduction}

In the 1930s archaeologists began to focus on First Spanish Cultural Period sites, which include the first discovery expeditions to Florida as well the missions and their effect on the Aboriginals. Historians have been interested in the route of Spanish explorer Hernando de Soto, and his four year expedition through the southern states. Very little evidence of the expedition has ever been found. Today controversy surrounds any attempt to document De Soto contact sites or mapping of a possible route his army may have used.

In 2005, a test excavation was started at the White Ranch site. The vast 289 hectare site is a dense woodland that contains wet savannahs, prairies, creeks and natural springs. Two sites on the project that are 1000 meters apart demonstrated unique European artifacts within the historical period and thus each site was chosen for rigid grid excavation. One site on the western border was identified as a contact site for the 1539 Hernando de Soto entrada and another distant site on the eastern border was identified as a $17^{\text {th }}$ century Franciscan mission based on artifact assemblage and the spatial interpretation of a structural foundation. Historical documents provide the locations of other missions in the area and the distances between them, but little is known of the 
mission of San Buenaventura or its predecessor the visita Apula. The identity as a Spanish mission is thoroughly analyzed in this research.

The analysis of the data from the site also tests the identification as a De Soto contact location. The artifact assemblage will be questioned against the most convincing evidence found at the Martin / De Soto site in Tallahassee, Florida and the Parkin site in Cross County, Arkansas.

Research for this study has involved lengthy historical investigation and detailed artifact analysis. This investigation uncovered new important evidence of First Period Spanish contact in Florida. This work will contribute to comparative study regarding Hernando de Soto's route through Florida and structural architecture of church mission style buildings.

\section{The following questions have directed this analysis:}

1. Is there evidence of multiple Spanish occupation or visitation at the site? If so what are the time frames associated with these occupations?

2. Does the site contain a Spanish mission structure? If so how can this be determined?

For this analysis, the date ranges of historic artifacts were analyzed to determine the European occupations. The first date range from the White Ranch west grid location indicates consensus corresponding to the early sixteenth century.

The second date range from the other site on the White Ranch in the east grid location indicates consensus corresponding with the seventeenth century. Coin and ceramic assemblages were compared to confirmed Florida mission sites and the early first discovery sites for the New World.

After completion of this study, the west site at the White Ranch clearly is a Hernando de Soto contact site. This site was then named as the White Ranch / De Soto site to delineate it from the distant eastern grid site.

The east site grid excavation thus far at the White Ranch site contains a seventeenth century Spanish structure which fits known dimension ranges of church missions and artifact assemblages within the range of the Spanish mission period and there is enough available data to confidently identify the site as the visita Apula the precursor of the Spanish mission San Buenaventura de Potano. After this confirmation the east grid site was then named the White Ranch / Mission site.

How did the results from this large project with varied sites coalesce? The decision was made in 2009 to have all of the information regarding the site, including location, digital images of all the artifacts, spatial context information and ground truth studies available to all individuals working in the field. This was done by placing all of the raw information, less the confidential grid locations; on a public website open to all with interest and then placing information that included latitudes, longitudes, property details and maps in the care of the Florida Department of State, Bureau of Archaeological Research in Tallahassee, Florida. On one of the first small assemblages recovered in context we got 52 excellent commentaries, primarily from six scholars. From that open discussion, consensus was achieved on identification and date range for those artifacts, and then the process was repeated with each item of material culture. There are related examples of these artifacts in several curated U.S. collections as well European museums, as the artifacts originated in Europe. Thus every effort was made to also find examples overseas for comparison and that was achieved. The artifacts were placed with the Appleton Museum of Art an American Alliance Accredited Museum and the Marion County Museum of History and Archaeology so professional archaeologists could have unlimited access for study, examination and testing. Over that three year period of open discussion, examination and testing a large volume of evidence confirming the date ranges was secured.

This paper is presented in a clear fast format based on archaeology field notes with the style note of capitalization of Aboriginal as we are properly referring to the extinct Timucua Indians and their relations.

\section{The Archaeology of Spanish Expeditions and Missions in Central Florida}

The expedition of Pánfilo de Narváez is the first recorded that documents a route through central Florida. In 1528 Narváez and Álvar Núñez Cabeza de Vaca landed near Tampa, Florida and were set to explore and occupy North America [1]. The expedition included several priests and five Franciscan friars [2]. The conquest immediately began to fail when support ships did not meet as planned with the marching explorers. Depleted of food, Narváez and his army were forced to eat their horses and melt many of their weapons to construct rough barges in hopes of sailing to Northern Mexico. A hurricane, starvation and disease reduced the number of men from 300 down to only four. Eight year later these few survivors were found by Spanish slavers on their way to Mexico City.

Next in 1539 we have the beginning of the expedition by conquistador Hernando de Soto. This exploration was a vast undertaking with more than 600 men and 200 horses. King Charles I of Spain required De Soto to bring the Catholic faith to the Aboriginals. Twelve priests were included in this mission, but historical documents indicate the Aboriginal people were treated harshly, many were killed, tortured or enslaved [2]. The De Soto route and contact with the Timucuan natives of Potano are confirmed with multiple source historic documentation [3].

In 1565 responding to the threat of the French claiming Florida, Pedro Menéndez de Avilés established St. Augustine, Florida. He next attacked and massacred the French at Fort Caroline and over the next weeks with more killings eliminated the French threat to Spain's claim. Philip II of Spain requested missionaries and Jesuit priests accompany Menéndez on this expedition, but historical documents identify only a few secular priests. After capturing and killing the remaining French soldiers one of these priests that accompanied the Spanish army as a chaplain related that this 
was the greatest victory which God had given them so that they may plant and preach the holy gospel in that area [1][2].

Spain continued with the Christianization of the Indians, by sending more missionaries to Florida. During the 1560s the Jesuits attempted to minister to the Tequesta, Calusa, Guale, and Orista Aborigines, but the effort failed and the missionaries withdrew in 1572. Franciscan priests arrived in St. Augustine, Florida in 1573. By 1587 the number of Franciscan priests had significantly increased and began to visit the Timucua, but it was not until the early 1600s that the Franciscans attempted to build missions in the Timucuan province villages of the Utina and Potano [2]. Timucuan missions spread to the west from St. Augustine to the Aucilla River where the Apalachee Indian provinces began [4] [5]. The natives of these villages were responsible for providing food for St. Augustine, but the feeling of forced labor and disease outbreaks were the start of a path to failure for this style of mission [6].

\section{Finding Spanish Expedition Sites in Central Florida}

Artifact evidence of the Narváez 1528 expedition has been scant and research continues, however early sixteenth century Spanish artifacts were found in the Marsh Island Mound. The assemblage includes glass beads, iron tools, and brass bells. This particular mound located in Wakulla County is believed to be near the Aboriginal town of Aute. Along the nearby St. Marks River within the St. Marks Wildlife Refuge other early sixteenth century glass beads have been discovered including the faceted chevron type and hawks bells of the Clarksdale type. These sites along Florida's panhandle coast are associated with the Bay of Horses area where the Narváez party launched into Apalachee Bay and began its doomed attempt to navigate to Mexico [1]. Historical documents relate that the ancient native town of Aute as well as the construction site of Narváez's primitive boats and horse skulls were discovered by Hernando de Soto's soldiers [7].

In the 1960s an early sixteenth century chevron bead and the same Clarksdale or hawks bell attributed to De Soto were discovered in Cross County, Arkansas. This location on the St. Francis River is known as the Parkin site. Later excavations in the 1990s revealed a .61 caliber lead shot and another similar lead fragment. The caliber corresponds to weapons carried by De Soto's army. There were also more fragments of bells discovered. This is convincing evidence suggesting this would be one of the towns mentioned by the chroniclers of De Soto's entrada. In the 1980s early sixteenth century glass beads were excavated from the Weeki Wachee Mound in Hernando County, Florida that are thought to have been left by the De Soto's expedition. Next more De Soto type artifacts were discovered in 1987 during a construction project at the location of a historic home built by Governor John Martin in the 1930s. These artifacts from the Tallahassee, Florida site were examined by Calvin Jones of the Florida Bureau of Archaeological Research and were determined to be from the early sixteenth century. There were fragments of glazed and unglazed Spanish pottery and glass trade beads. The beads were identified as faceted chevron and Nueva Cadiz types. A metal cross bow arrow point as well a remnant of mail armor that would have been wore by Hernando de Soto's soldiers and a skeletal fragment of a domestic pig (Sus scrofa) and copper coins were recovered at the construction site. Together this assemblage of artifacts all within the same context range of the early sixteenth century confirms the De Soto contact. In 1988 an excavation beside the Withlacoochee River at a site called the Tatham Mound of Citrus County, native burials were discovered. Bioarchaeological examination of the bones exhibited wounds from sharp edged weapons, suggesting the tool marks were from Spanish swords. Faceted chevron beads that were known to exist in the early sixteen century were also excavated [1].

\section{Finding Spanish Mission Sites in Central Florida}

After the discovery of a Spanish mission site in the 1950s the State of Florida Division of Historical Resources began a discovery project, to locate, excavate and identify others. By the $1970 \mathrm{~s}$ at least ten mission sites had been confirmed. The multiple written accounts from Hernando de Soto's entrada, though more than 450 years old, were vital in assisting with the mission locations. These detailed historical documents provide evidence as to the names of the villages that De Soto visited and many of these same villages became mission sites in the seventeenth century [1] [3].

Archaeologists and historians used the distances given from known villages as well St. Augustine to assist with the locations of the missions. Some of the documents that provided the best references were: La Florida by Garcilaso de la Vega [8], the Relation of the Island of Florida by Luys Hernandez de Biedma, the Account of the Northern Conquest and Discovery of Hernando de Soto, and the Account by Gentleman From Elvas [3], the 1657 visitation account of Spanish Governor Robolledo [6], and the documentation from Bishop Don Gabriela Díaz Vara Calderón's 1674 visit to Florida [9]. Bishop Calderón's account listed 36 missions [2]. Mapping these villages revealed the Spanish attempted equidistance between the missions and this led to the discovery and identity of others, yet some discovered still await confirmation [10].

The historical record of Spanish mission sites near 8AAMR03538 includes the Acuera villages in the Ocklawaha drainage and its missions Santa Lucia de Acuera and San Luis de Acuera or Avino. Mission Santa Lucia de Acuera was discovered by artifact collectors in the 1970s. Because the location in an agricultural field has been so widely known for the past forty years the site has suffered from continual looting.

One detail uncovered in the course of this research showed before the discovery of the mission locations along the Ocklawaha basin, some were misplaced as their written descriptions detailed the distances from one another traveling downstream. Early researchers may have been unaware of the anomaly that the Ocklawaha River flows north. Thus identity of those missions without that reference qualification may be in question. 
The location of the mission of San Luis de Eloquale was at one time thought to correlate with the village named on the 1591 color engraving by Theodor de Bry of Jacques le Moyne de Morgues's 1564 map, but the actual location is believed to have been located to the southwest of 8AAMR03538 in the Ocale village on the east side of the Withlacoochee River. To the direct east of 8AAMR03538 on the shore of Lake George, is the site of San Antonio de Encape and to the north we find several early missions in Alachua County [1].

The Alachua mission of San Francisco de Potano was founded in 1606 by the Franciscans Father Martín Prieto and Father Alonso Serrano. It was the first doctrina (a mission with a resident priest) in Florida west of the St. Johns River. The mission was at the south edge of present-day San Felasco Hammock Preserve State Park [11].

The Potano Indians were enemies of the Spanish for some 30 years after the founding of St. Augustine in 1565. In 1597 the chiefs of the Potano and other Western Timucuan tribes had pledged allegiance to the governor of La Florida in St. Augustine. Franciscan missionaries began visiting Western Timucuan villages that year, but a rebellion in the Guale Province disrupted missionary efforts in Florida for a decade. Missionaries continued to make occasional visits, but permanent missions were not established, even though chiefs requested them and returned to St. Augustine to renew their vows of allegiance to the Spanish authorities. The arrival of additional Franciscan missionaries in 1605 allowed the establishment of permanent missions in Western Timucua to proceed, beginning with the mission of San Francisco de Potano in 1606 [11].

Soon after Father Prieto and Serrano established the mission of San Francisco, Father Prieto established the nearby missions of Santa Ana de Potano and San Miguel de Potano. Opposition from the villagers at San Francisco de Potano forced Father Prieto to return to St. Augustine and the mission became a visita (mission without a resident priest) served by Father Serrano, who resided at the mission of San Miguel de Potano. A fourth mission, San Buenaventura de Potano was established a short time later with Fray Francisco Pareja. This mission was located to the south of the other Potano missions, central to the string of villages along the wetlands of the Orange Lake area. This mission was easily accessible from St. Augustine via the St. Johns and Ocklawaha Rivers and then overland a short distance. Initially, the four Potano missions served about 1,200 Indians, about 400 of whom were at San Francisco.

Luis Jerónimo de Oré, a Franciscan and expert in Quechua and Aymara, visited the Potano territory in the early 1600s. He published his religious chronicle entitled Relacion de los martires que a avido en las provincias de la Florida in Madrid ca. 1617. It is a bibliographical rarity and includes a visit to the mission San Buenaventura de Potano and describes his route. This gives us the earliest terminal date for the mission at 1616.

By 1704 mission San Francisco de Potano was fortified and one of the few Spanish outposts left west of the St. Johns River. The remaining Indians at San Francisco moved east of the St. Johns River in 1706, abandoning the mission 100 years after it was established [12].

\section{Confirming the Discovery of a Hernando de Soto Contact Site at 8AAMR03538}

As we have seen there are also other instances of conquest discovery sites involving early sixteen century glass beads in the Florida Aboriginal mounds of Weeki Wachee, Tatham, and Marsh Island. These glass trade beads help form the framework needed to began a list of the required artifact evidence to confirm a Hernando de Soto exposure. Some of the strongest evidence to date of a site being exposed to De Soto's expedition is based on the artifact assemblages from the Martin site in Tallahassee, Florida and the Parkin site in Cross County, Arkansas [13]. If the threshold is set high with the tested standard that a site must contain a sampling of all of these type artifacts within the same context and date range of the early sixteenth century, we can confidently defend the hypothesis. Thus according to this strict definition, to be confirmed as a Hernando de Soto contact site, the following criteria must be met:

1. European imported iron/metal items.

2. European imported glass / ceramic items.

3. European imported copper items.

4. European imported domestic animal remains.

The early sixteenth century artifact assemblage from the west grid excavation of the White Ranch / De Soto site is broad and within context contains samples from the required categories. First, the evidence of the European iron items takes the form of mail armor. The Hernando de Soto chronicles discuss their use of Milan type mail armor and a demonstration by a Native Indian warrior in his ability to pierce two layers of Milan mail with a bow and arrow. Multiple excellent examples of mail armor and individual rings of mail have been recovered from the White Ranch / De Soto site. Even with XFR testing it seems an impossibility to identify the center of manufacturing; however multiple curators confirmed the European four-in-one and five-in-one patterns, and XFR elemental analysis reconfirmed the date range. There were other numerous metal artifacts in the forms of .61 caliber lead shot, designed for medieval harquebus matchlock firearms and iron crossbow bolts of the $15^{\text {th }}$ and $16^{\text {th }}$ century type.

Second, numerous Nueva Cadiz beads dated to 1520, as well as, multiple faceted glass chevron trade beads with seven layers dated from the early sixteenth century have been excavated and recorded from the White Ranch / De Soto site. The De Soto chevrons followed the pattern blue, white, blue, white, red, white and blue from the inside out, with some demonstrating green tints on the inner most layers. Numerous Goggin's Early Style Olive Jar fragments were recovered that reconfirm the ceramic date range. Together these bead types and potsherds satisfy the defined European glass / ceramic items. 
Third, the evidence for the European copper items was discovered in the form of Spanish coins. These three coins are described as: 1. Ferdinand and Isabella, 1497-1504; cuarto de 4 maravedi, Granada mint uncertain. 2. Ferdinand and Isabella 1497-1504; cuarto de 4 maravedi; mint Cuenca. 3. Enrique IV, 1454-1474, blanca, 1471-74 mint uncertain. These are exactly the coins expected to be recovered from a moving mercenary army such as De Soto's.

Fourth, the evidence of European imported animals is supported by the discovery of the (Sus scofa) domestic pig remains, introduced to Florida by Hernando de Soto. The artifacts consist of a near complete intact mandible with 21 teeth and a maxilla which even under the most careful standards and plaster recovery disintegrated but contained 22 teeth. Collagen was recovered from both ten gram harvest samples of the compact bone from the mandible and the date calibrated from the 2 sigma $95.4 \%$ confidence interval centered at the year 1540 .

The very high threshold standard that artifact types from each group and date range have to be discovered within the same context has been achieved. With all of the required criteria met, the White Ranch west grid location can be confirmed as a Hernando de Soto contact site.

\section{The location of MR03538 - Historical Evidence}

Hernando de Soto's expedition is primarily known to archaeologists and historians through four accounts or chronicles. Three are confirmed as first hand. These are: 1 . The Relation of the Island of Florida by Luys Hernandez de Biedma 2. The Account by Gentleman From Elvas 3. The account of Hernando de Soto's official secretary Rodrigo Rangel. The fourth document considered a second hand romantic interpretation is known as La Florida by Garcilaso de la Vega. Each of these narrative documents offers some details and combined in a Mosaic or braided form provides an accurate reference. Time and distance in these documents require conversion for accurate reconstruction of De Soto's route. Primarily understanding that the Old Style Julian Calendar was in use until 1582 and that Spaniards used different forms of league measurements [3].

On July $26^{\text {th }}$ of the Old Style Julian Calendar, De Soto's expedition entered the swamp and peat bog bordering Florida's Withlacoochee River. The Aboriginals continuously ambushed De Soto and his advance guard by shooting arrows and then vanishing into the thick surroundings. After a difficult crossing over the Withlacoochee De Soto made camp at Ocale and sent word for his army to follow. The location of this ancient village is southwest of the modern city of Ocala in Marion County, Florida. Over the next week of bivouac the Aborigines injured and killed several of the soldiers. What followed next can only be described as a terror campaign which included psychological warfare orchestrated by the Aboriginal Indian warriors. They captured and beheaded two of De Soto's men and when the army retrieved the bodies for burial, the stealthy natives returned during the dark of night and dug up the corpses. The army awoke to the horrible sights and sounds of birds eating their comrades, which had been cut into small pieces and hung in the trees like ornaments.

After enough corn was seized for the army to be maintained, De Soto made the decision to continue northward. On August $11^{\text {th }}$ De Soto left the main part of the army behind and he continued on with an advance party of one hundred crossbow infantry men and fifty knights with lances on horseback. By nightfall the chronicles confirm they reached the village of Itarraholata and found an ample corn supply. Itarraholata is also within Marion County, Florida on the same latitude as Ocala. The next day De Soto came to the main area of Potano. The Potano like the Itarraholata were considered part of the Alachua archaeological culture, which built their villages on the edges of lakes and prairies. De Soto stayed with the Potano and visited their main city which is believed to have been on the south and west edge of the Orange Lake which extends into the Black Sink Prairie. After leaving the Potano De Soto continued north and one week later he sent eight horsemen to retrieve the rest of the army, which had been camped south of Potano. The chronicles tell that then Luis de Moscoso, the master of camp, led the army to meet De Soto and as well marched to and bivouacked in Potano. Moscoso and the army did not rejoin De Soto until September $4^{\text {th }}$. Undoubtedly and without discrepancies the historical documents confirm Hernando de Soto had contact with the people of Potano in the area of the White Ranch.

\section{Confirming the Discovery of a Spanish Mission at 8AAMR03538}

When comparing seventeenth century Spanish mission sites certain characteristics are used for assessment. One of the first commonalities found is usually evidence of a Spanish structure and its proximity to a drinkable water source, often a spring or karst sink. The artifact types required for proof have been found at other confirmed mission sites and are within context and date range. In 1990 Calvin Jones and Gary Shapiro studied nine Florida missions and developed a list of criteria that help investigators when they are evaluating Spanish mission sites. The items on their list are part of the following improved list:

1. Fresh water access.

2. Rectangular structure.

3. Level floor consisting of dried clay or gumbo.

4. European imported metal items.

5. European imported ceramic.

6. Wattle and daub or plank siding.

7. Aboriginal artifacts.

The artifact assemblage from the east grid excavation of the White Ranch contains items all found within context of other seventeenth century Spanish mission sites.

First, the evidence of fresh water access is confirmed by a stream fed fresh water sink 30 meters to the west of the remains of a structural foundation at the White Ranch / Mission site.

Second, there is evidence that the structure had a rectangular floor plan. 
Third, there is only indirect evidence of a level floor. The original floor if it ever existed was destroyed when the site was previously used as a sand borrow pit. The sand removal extended to a meter in depth and would have removed any level floor. There are remaining post holes which are of similar depth and elevation, which relate strong circumstantial evidence that such a floor may have existed. The depth of the post holes all cease at a naturally occurring virgin layer of dense gumbo clay, which has proven to be nearly un-penetrable.

Fourth, the evidence of imported European metal items takes the form of a cache of Spanish maravedis coins. These coins were minted in various places throughout Spain during the realms of Felipe II (1566-1598), Felipe III (1598-1621) and Felipe IV (1621-1665), strongly suggesting a seventeenth century mission site. Spanish sites around Orange Lake were also involved with cattle ranching, as well as smuggling and trade to avoid taxes required to be paid in St. Augustine and this cache of coins is expected in the artifact assemblage from this date range [14]. There have been rare instances of iron items in the forms of spikes and nails discovered at Spanish mission sites, but there is no confirmed evidence of imported iron items within the required date range. Iron items were recovered during the surface survey of the White Ranch / Mission site. Square cut nails of 10 centimeters in length were unearthed throughout the borrow pit area and an iron hoe near the south border of the structural remains. The square nails and the hoe were in common use during the nineteenth and twentieth centuries. These artifacts confirm one of the known uses of the site as a naval stores production area. The hoe was used to channel trees for turpentine and the nails remain from some type of siviculture support structure.

Fifth, imported European ceramics within the date range of seventeenth century mission sites were recovered at the White Ranch east grid location. The discovery of Spanish majolica, a late $16^{\text {th }}$ to early $17^{\text {th }}$ century type made in Seville, called Ichtucknee Blue on White is significant as it has only been found at other Franciscan missions. Numerous plain blue tint translucent glass beads, including light blue, turquoise and cobalt colors and non-colored beads have been recovered at the White Ranch / Mission site as well as at other $17^{\text {th }}$ century Florida Spanish mission sites. These are considered important indicators of Spanish mission activity. The beautiful multi layered blue, red and white glass beads are from a known type of Franciscan Crown Rosary gifted to select Franciscans, as well several other religious orders. This style of glass Rosary originated from the Venetian Island of Murano and examples exist as early as the 1400 s, but this unique style is thought to have been produced from ca. 1680 and continued to 1740 . These dates are beyond the expected terminal date of the San Buenavenura de Potano mission, but within the date range of Buenaventura's nearby doctrina mission San Francisco de Potano and the Spanish ranching activity involved with the Hacienda de la Chua, both which continued operation into the early 1700 s.

Sixth, there is little evidence of what type of siding, if any was used on the Spanish structure. Based on the extended depth of the previous sand removal when the site was used as a borrow pit any remaining wattle and daub or plank siding would have been displaced. There is evidence however that contradicts this criterion as a guideline for a mission site. The Timucua Fig. Springs site considered to be the confirmed site of Mission San Martin de Timucua was considered an open air church, because there was no evidence of wattle and daub recovered.

Seventh, around the site there are scattered Aboriginal lithic artifacts and groups of the ones recovered can be dated within the seventeenth century mission period. Some were ancient and consisted of flakes of heated and worked chert as well paleo points from the mid Archaic to the end of the Ice Age. This demonstrates years of occupation due to fresh water and hunting ground access. Numbers of Indian ceramics from the Potano culture, that extended into the seventeenth century were also confirmed, as well those of other proto-Potano cultures. Of note, this area amongst the shores of the Black Sink, Gooskie and Orange Lake wetlands has been long known as a site to search for Aboriginal pot sherds and in 1979 neighbors of the site reported that a university set up camp here and excavated the burial mounds for six weeks. Neighbors interviewed reported seeing thousands of Aboriginal ceramics and lithic tools on examination tables, as well as, dozens of sets of human remains, yet no records can be located, though a few photographs of the field school encampment have been recovered. Because of the shape and alignment of displaced earth there is strong evidence of sub floor burials having been removed from the east mission location. These unrecorded excavations along with the huge displacement of the site for road fill leaves the investigator only with speculation.

Based on the extended date range of the Rosary and coins at this time we can only use the outline of ethno-history to form hypotheses about what events were associated with those artifacts. We know that the boundaries of the Hacienda de la Chua the "ranch of the sinkhole" encompassed this site. This Spanish ranching operation began in 1646, though ranching is known to have begun early in this area, but we have no names of the ranches. This ranch was operated by the Menéndez Marquéz family, who were related to Pedro Menéndez de Avilés, the founder of St. Augustine. The latter half of seventeenth century in the Potano area was a tumultuous period. We have epidemics of typhus and yellow fever in 1648 and 49 , then a plague of smallpox in 1655, which was followed by extensive famine. Those events led to The Great Rebellion of 1656, which was an eight month civil war between loyal and rebel Indians and as that was ending there was a devastating measles epidemic. In just these few short years tens of thousands of people had died in the Timucuan region. In 1668 English buccaneer Robert Searle raided the area; and then in the early 1670 s the ranch began smuggling livestock products to Havana in exchange for rum and then traded the rum to Apalachee for furs. By using the Gulf route to Cuba, Hacienda de la Chua avoided the Customs House and taxes in St. Augustine. In 1672 there was another measles epidemic and Bishop Don Gabriela Díaz Vara Calderón 
visited the area in 1674 . In 1680 began what is called the Wars of the Florida Provinces and that continued until 1706. During those wars French buccaneers twice raided the ranch; first in 1682 they burned the buildings and kidnapped the family, then demanded a ransom of many cattle and a purse of money. They attacked La Chua again in 1684. After that, English-allied Indian forces raided the Potano area in 1703 and then violent attacks from the Creeks, pirates and slave traders continued and at one point they captured and quartered a La Chua rancher. Not long after in 1706, the ranch was burned and abandoned [14]. One can only speculate that any number of those many cataclysmic events could be associated with the artifacts outside of the expected terminal date range of religious activities for the White Ranch / Mission site.

Reviewing the most notable characteristics we have confirmed the existence of a Spanish structure, nearby fresh water source, imported European ceramics and metal artifacts that have been found at other confirmed mission sites. The date range of the recovered artifacts and the structural evidence at the White Ranch east grid location confirms this is the original location of the visita Apula and the Franciscan Buenaventura de Potano mission and that it was occupied during the seventeenth century mission period.

\section{Excavation History of Site 8AAMR03538}

Information for this research was gathered from the Florida Master Site File, field notes, artifact and site sketches, photography of the site and direct analysis of the artifact assemblages. Correspondence between the investigators and archaeologists which specialize in La Florida's First Spanish Period provide a consensus on artifact identification. Detailed GIS information was provided by Dr. Richard Estabrook, Director for the Central Region of the Florida Public Archaeology Network and that information helped locate the posthole outline of the Spanish structure. These ground penetrating radar and metal detection studies were used as a starting location for test hole excavation units. These test holes were one meter by one meter in size and ranged in depth from 20 centimeters to 200 centimeters. Several test areas revealed solid limestone at only 20 centimeters below the surface and could not be deepened. In areas determined to have artifacts a rigid grid system was established to maintain horizontal control. All measurements being made in meters north and east of a set point southwest of the site. Vertical control was assured with Zeiss levels and transits as well laser projections to fix the datum plane. The datum plane and rigid grid system were tied in with permanent monuments and modern GIS satellite reference points. Excavation sub units were laid out in two meter squares referenced by their southwest corner grid number. All was done with a sifter using $1 / 8$ inch mesh, and resifted using window screen in areas of small artifact discovery. The excavation schema reveals 5 clusters of excavations with 13 two meter square subunit groups, with one meter extensions as needed incorporating previous test holes and 71 additional $2 \times 2$ grids in remote areas where test holes produced positive results.

\section{Structural Analysis of 8AAMR03538 Compared to Known Mission Sites}

Today there is only limited evidence of the design of Florida mission structures [2]. We known Calvin Jones and Gary Shapiro completed studies of nine Florida missions in 1990 and then developed a list of criteria that help frame evidence needed for confirmation as a Spanish mission site. Their research stated that a Florida mission complex usually consists of at a minimum of two buildings. A rectangular church and a small square convento sometimes accompanied with an additional kitchen (cocina) structure [6]. Since the excavations of the sites were quite limited this proposal is considered only a best guess prediction and should not be a required template. The structure size range for the church buildings reported in the Jones and Shapiro study are consistently from 11 meters to 12.6 meters in width and 17.8 meters to 26 meters in length. The structure at 8AAMR03538 measures from 11 meters in width and 19 meters in length, clearly within the known criteria for both fields [4]. There is evidence of post holes and soil staining appearing at .84 meter intervals around the outline of the exposed part of this rectangle. This spacing correlates with the Spanish vara which is 32.908 inches or .8359 meters. In overall dimensions calculated for the Spanish measurements, the width is 13 vara and the length 23 vara. The post holes encompassed within hard clay have a diameter average of $20 \mathrm{~cm}$ along the perimeter and centrally the post hole sizes are larger averaging $40 \mathrm{~cm}$. These central post holes may correlate to load bearing support posts and appear larger than ones used by the Aboriginal peoples in their structures. There is some but limited evidence of remaining wooden posts, iron spike nails, wattle and daub siding, or the remains of a prepared clay floor at 8AAMR03538.

\section{Building Orientation}

There is currently such limited excavation information about confirmed seventeenth century Spanish mission structures that the building's orientations appear to follow no set pattern. Further excavation of known mission sites and the ability to define what structures are present would be the only way to confirm orientations. The remains of the Spanish foundation at the White Ranch / Mission site first appeared to be oriented in no specific direction, for example facing the stream or open prairie. The Spanish were known to divide land parcels on what is called the Spanish Slant, an angle 45 degrees off from North, but the rectangle does not follow that orientation either. After sighting with a Keuffel \& Esser level compass followed by a Young and Sons survey transit the foundation parallels a line that if continued southeast would exist between 116 to 117 degrees. Laurent A. Pellerin, Jr., Planetarium Coordinator for the Kika Silva Pla Planetarium at Santa Fe College confirmed the winter solstice azimuth would be within this range, and during the early 1600 s would have been $116 \mathrm{deg} 41.489 \mathrm{~min}$. These findings are preliminary and 
site visits will be coordinated to document any further archaeoastronomy and ethnoastronomy evidence.

The evidence of internal post holes within a rectangular layout follows the design of known Spanish mission aisled churches. The 11 meter by 19 meter pattern incorporating the vara in the design features can be identified at this time as the remains of a seventeenth century Spanish aisled church.

\section{Analysis and Provenience of Artifacts from 8AAMR03538}

This research is part of the continued analysis of the artifact assemblage and architectural remains from the White Ranch / De Soto site and the artifact assemblage from the White Ranch / Mission site. Numerous labeled field bags and boxes of artifacts containing accurate provenience information were cleaned and photographed. The artifacts were confirmed for space and time locations based on original horizontal control with photographic evidence and field notes. There is evidence of Aboriginal habitation and multiple Spanish occupations.

\section{Historical Period Chronology Overview}

The Hernando de Soto 1539 Ocala Encampment (AD July September 1539)

The visita Apula (AD ca 1580 - burned in 1584)

The original location for the San Buenaventura de Potano mission (AD 1607 - ca 1616)

Historical documents absolutely confirm the Franciscan mission of San Buenaventura de Potano was relocated closer to Orange Lake at the beginning of the $17^{\text {th }}$ century to the Richardson site.

Possible earliest terminal date is based on the report of Luis Gerónimo de Oré's inspection of the Apula visita in 1616, published in 1617 Madrid.

European artifacts recovered at the White Ranch / Mission site have an extended date range to the beginning of the $18^{\text {th }}$ century confirming the site's association with the Hacienda de la Chua Spanish ranching operation that ended in 1706.

\section{Notes on the adjacent Richardson site:}

It is a near certainty that the 1539 army of De Soto traversed near the Richardson site, as it is on the direct path north to Apalachee though no early $16^{\text {th }}$ century European artifacts have ever been discovered at the site. Spanish material artifacts have been collected from the Richardson site confirming it is the relocated site of a $17^{\text {th }}$ century Spanish mission and those include John M. Goggin's middle style olive jar sherds, majolica sherds with a type of Ichtucknee Blue on Blue, as well plain blue trade beads. Ethnographic history of the Potano province indicates that Fray Baltasar Lopez from San Pedro de Mocamo made two trips to the region in 1600 and 1602. In 1968 Goggin seriated the Spanish materials collected at the nearby Richardson site at 1615 , with a terminal date of pre-1650, as the Richardson site collection does not contain Leon-Jefferson ceramic inventory. However beginning in 2013 there have been repeated attempts to link rare early style olive jar artifacts somehow to the Richardson site making it seem older than it actually is. This is antithetical to fact as the top scholar on Spanish olive jar typology, Professor John M. Goggin from the University of Florida had previously published a decade long analysis of the 5159 Spanish and Indian potsherds from that site that completely disprove such claims. It turns out the site only contained middle style olive jar sherds dating in range $c a$. A.D. 1580 to 1780 [15]. This date range for the Richardson site is very accurate and cannot be scientifically disputed. The fact of never finding European artifacts at that site in the early date range of the Narváez and De Soto entradas (A.D. 1528-1539) strongly upholds the conclusion the site was not occupied by the Spanish at that time and is not a De Soto entrada site. It also raises serious questions about the miraculous claim of early ceramics at the Richardson site that came only after an entire collection of Goggin's early $16^{\text {th }}$ century style olive jar artifacts from the confirmed White Ranch / De Soto site could not be located in museum storage. It is now the solid consensus opinion of scholars that the artifacts from the White Ranch / De Soto site could have been presented to academics visiting the Richardson site and they unknowingly agreed that the Richardson site was older unaware of the provenience of the artifacts. The early $16^{\text {th }}$ century typology and TL confirmed artifacts from the White Ranch / De Soto site were placed on loan at the Marion County Museum of History and Archaeology in November of 2012 and are still missing today.

It appears European contact at the Richardson site is limited to $17^{\text {th }}$ century Spanish missionary activity. It is known that the Potano moved from some of their pre-historic villages like Apula to Spanish occupied areas north of Orange Lake. This research confirms Spanish priests set up the Apula visita at the White Ranch site as it predates the Richardson site in European material culture and this area would have been central to several villages. At some period in the very early $17^{\text {th }}$ century the mission activity of San Buenaventura de Potano that began at the ancient Apula site was relocated to the Richardson site and our findings of non aboriginal features at that site concur. In 2003 we began a longitudinal study of the available metadata from the Richardson site. The metadata included writings and maps from the University of Florida field schools that span from the 1940s with Dr. John M. Goggins to Dr. Charles H. Fairbanks and Dr. Jerald T. Milanich in the 1970s and included several volumes of unpublished field notes written by Ripley P. Bullen, Curator Emeritus at the Florida Museum of Natural History at the University of Florida that remain in a private collection. In 2005 a computer CAD designed three dimensional map of the site was created using all of the previous maps and it identified a long section of a seventeenth century mission wall with 90 degree corners that fit the parameters of a Spanish mission church confirming the mission activity had been relocated from the older 8AAMR03538 site [16].

Relocations of Native villages to compensate for changes in hunting and fishing grounds are logical, the water levels on these prairies are quite dynamic and go through cycles lasting many years. The Black Sink Prairie has a history of drying up for long periods and is then used for cattle grazing, as there are 
still permanent fresh water sinks spaced along it. Orange Lake has the same history related to climate and sinkhole activity. One can easily see these Native Indian movements are migratory and not an exodus, and as such the missionary activity would follow its target population. There is clear historical evidence that a Potano chief met with the Spanish Governor Mendez de Canco in the early 1600s in St. Augustine. The chief wanted to discuss resettlement of the town of Potano closer to Orange Lake. The Spanish had burned Potano years earlier during a raid in 1584 . The request for relocation thus would appear not to be associated with the results of that raid. The European material culture demonstrates the White Ranch site continued occupation as a possible Spanish ranching outpost. Cattle ranching began in the Potano area in the early 1600 s and this location was known to be within the Hacienda de la Chua area that was in operation from (AD 1646 - 1706).

At this point it is important to note that there is a supportable hypothesis that the assemblage of 7 layer faceted chevrons, Nueva Cadiz beads, mail armor and Spanish coins could be from the 1528 Pánfilo de Narváez expedition through central Florida. Ethno historic information confirms the 1528 entrada began at the landing near Tampa and the army accompanied by Franciscan friars and priests traversed north within the Timucua territory. Efforts to reconstruct the route place it in Marion County, Florida where the Spanish encountered the Timucua in early June of 1528 . The placement of the Narváez route based on a University of West Florida Archaeology Institute map approximates it could have been in the range of 8 to 12 miles from the White Ranch site. All reconstructed routes based on historical accounts demonstrate that Hernando de Soto at times visited the same exact locations as Pánfilo de Narváez and their routes crossed in Marion County. De Soto's chronicles confirm interactions with the same chiefdoms visited by Narváez and even describe De Soto's soldiers finding the remains of Narváez's horses near the St. Marks River. Throughout the chronicles that describe both army's expeditions there are descriptions of continuous scouting parties, that are looking for better routes and sources of food. They go off in multiple directions and would most likely be separated from the main army for days. It is probable that De Soto's advance parties and even the main body of the army at times camped in the same locations that had been visited by Narváez, as both Narváez and De Soto were often being led by Native Indian guides that wanted these armies to quickly move north out of their territories. The only difference in the assemblages would be De Soto's could contain domesticated pig remains. We know that domestic pig remains were found at the White Ranch / De Soto site 15 meters west of the dense early sixteenth century assemblage in a one meter by one meter test excavation. It is a near impossibility to determine if it belongs in a different context as the depth of recovery in the strata was the same. As we have seen it is probable that the site could have been visited by members from both groups, and the window of time is very tight at only 11 years apart. That distance of time could be represented in these soil mixtures as only one centimeter depending on the depth of organics rendering that measurement undistinguishable. The integrity of the site after centuries of continuous use in siviculture, ranching and mining offers difficulty in spatial relationships.

\section{Conclusions and Recommendations}

The Spanish artifact assemblage of the White Ranch / De Soto site confirms Spanish contact during the early part of the sixteenth century. The historical evidence also confirms this is the area visited by Hernando de Soto the Spanish explorer and conquistador in August of 1539. The location of the White Ranch / De Soto site is within the Timucuan Potano tribe area north of Ocala, Florida detailed in the De Soto chronicles.

The 8AAMR03538west grid location known as the White Ranch / De Soto site now joins the Governor Martin Site at the Apalachee village of Anhaic east of Tallahassee, Florida as the only sites confirmed with Adelantado Hernando de Soto's entrada. These significant sites correlate with the evidence and progress ethno historians, anthropologists, and archaeologists have contributed to reconstruct De Soto's route. In 1997 after more than fifteen years of research Charles M. Hudson working with numerous scholars reconstructed the closest route to the actual expedition thus far. The map was published that same year by the University of Georgia Press [3]. The map route evidence corresponds with the original first hand chronicles and the actual site location of the White Ranch / De Soto site. The early $16^{\text {th }}$ century artifacts that prove Spanish occupation are currently held in the historical archaeology research collection at the University of Florida Museum of Natural History.

The Spanish artifact assemblage of the White Ranch / Mission site along with the evidence of a Spanish structure at this location can at this time be confirmed as a Spanish mission site. The evidence is sufficient to identify occupation of the site during the sixteenth and seventeenth century mission periods and design and construction of a Spanish aisled church. The structural remains fit the architectural parameters of known Spanish mission building dimensions and further excavation located a cocina, with the associated ceramics confirming the Franciscan occupation. Exhaustive team excavation continued to locate other mission structures and none were discovered. Artifact recovery and survey were completed in 2013 and the site was closed.

Though no artifacts remained and the grid excavations had been back filled with sand at all of the ranch sites, trespassers continued to enter and dug hundreds of holes throughout the property in 2014, removed permanent survey markers and forever damaged the surrounding context preventing any future investigation.

Going forward because of the conclusive evidence that the 8AAMR03538 east excavation grid contained a $16^{\text {th }}$ century Spanish visita mission and later a larger $17^{\text {th }}$ century Franciscan mission with a cocina structure, the investigation could be expanded beyond the borders of the White Ranch to include the burial mound area excavated in 1979. A remote argument could be made that the nearby Aboriginal mound 
area could contain accessory aligned Christian style burials within the grounds of the known mound complex. This would be an anomaly as well as a significant finding demonstrating a transition between the Aboriginal beliefs and First Spanish Cultural Period Christianity. Mission history relates there was strong resistance among the Potano to accept parts of the Christian structure and the date range associated with the visita Apula shows it was one of the earliest attempts at conversion. In discussing this transition or early melding of beliefs we are struck with the evidence that the confirmed Spanish structural remains align with the winter solstice azimuth. This evidence along with the lack of wattle and daub siding could suggest this was a more primitive structure with some applied Aboriginal design features. Further study has begun to compare the 8AAMR03538 mission structure with the open air church confirmed at Mission San Martin de Tiтисиа.

\section{References}

[1] Milanich, Jerald T., 1995 Florida Indians and the Invasion from Europe. University Press of Florida, Gainesville.

[2] Thomas, David Hurst (editor), 1990 Columbian Consequences: 2. Archaeological and Historical Perspectives on the Spanish Borderlands East. Smithsonian Institution Press, Washington, D. C.

[3] Hudson, Charles, 1997 Knights of Spain, Warriors of the Sun, The University of Georgia Press, Athens and London.

[4] Milanich, Jerald T., 1999 Laboring in the Fields of the Lord: Spanish Missions and Southeastern Indians. Smithsonian Institution Press, Washington.

[5] Weisman, Brent Richards, 1992 Excavations on the Franciscan Frontier: Archaeology at the Fig. Springs Mission. University Press of Florida, Gainesville.

[6] Jones, B. Calvin, and Gary Shapiro, 1990 Nine Missions of Apalachee. In Columbian Consequences: Volume 2. Archaeological and Historical Perspectives on the Spanish Borderlands East, edited by David Hurst Thomas. Smithsonian Institution Press, Washington, D. C.
[7] Gannon, Michael V., 1996 The New History of Florida. University of Florida Press, Gainesville.

[8] Clayton, Lawrence A., Vernon James Knight, Jr. and Edward C. Moore (editors), 1993 The De Soto Chronicles: The Expedition of Hernando De Soto to North America in 1539-1543. University of Alabama Press, Tuscaloosa.

[9] Gannon, Michael V., 1965 The Cross in the Sand: The Early Catholic Church in Florida, 1513-1870. University of Florida Press, Gainesville.

[10] Jones, B. Calvin, 1973 A Semi-Subterranean Structure at Mission San Joseph de Ocuya, Jefferson County, Florida. In Bureau of Historic Sites and Properties Bulletin No. 3, Division of Archives, History, and Records Management, pp. 1-50. Florida Department of State, Tallahassee.

[11] Milanich, Jerald T., 2006 Laboring in the Fields of the Lord: Spanish Missions and Southeastern Indians. University Press of Florida, Gainesville.

[12] Wenhold, Lucy L. Translator and Ed., 1936 “A 17th Century Letter of Gabriel Diaz Vara Calderón, Bishop of Cuba, Describing the Indians and Indian Missions of Florida." Smithsonian Miscellaneous Collections, Vol. 95, No. 16. Reprinted in David Hurst Thomas. Ed. (1991). Spanish Borderlands Sourcebooks 23 The Missions of Spanish Florida. Garland Publishing.

[13] Ewen, Charles R. and John H. Hann, 1998Hernando de Soto Among the Apalachee: The Archaeology of the First Winter Encampment, Gainesville, FL: University Press of Florida.

[14] Bushnell, Amy, 1978 The Menéndez Marquéz Cattle Barony at La Chua and the Determinants of Economic Expansion in Seventeenth-Century Florida. The Florida Historical Quarterly, Vol. 56, No. 4, pp. 407-431. Florida Historical Society.

[15] Goggin, John, 1968 Spanish Majolica in the New World. Yale University Publications in Anthropology, no 72. Yale University Press, New Haven.

[16] White, Fred, 2010 The Richardson Site 8AL100 and its association with the discoveries at the White / De Soto Site 8AAMR03538 of the town of Potano and the mission of San Buenaventura. Tallahassee, FL: Florida Department of State, Bureau of Archaeological Research, Master Site File MR03538. 